\title{
Physical and chemical properties of granulated cane sugar "panelas"
}

\author{
Propriedades físicas e químicas de rapaduras granuladas
}

\author{
Marisa Josefina GUERRA ${ }^{1 \star}$, María Virginia MUJICA²
}

\begin{abstract}
"Panela" is a natural sweetener obtained by concentrating sugar cane juice and handmade in small factories. In the study carried out, the physical and chemical properties of two commercial brands of artisanal granulated panelas and of one made on an experimental level were determined. Three lots of each sample were analyzed. The parameters measured were moisture, $\mathrm{a}_{\mathrm{w}}$, protein, ash, minerals, reducing sugars, sucrose, $\mathrm{pH}$, color ( $\mathrm{L}$, a and b), insoluble solids (IS), transmittance a $720 \mathrm{~nm}$ and filterability. In addition, a qualitative test to detect sulphur dioxide was performed. The parameters with higher variability were moisture (1.66-4.36 g.100 g $\left.\mathrm{g}^{-1}\right)$, $\mathrm{a}_{\mathrm{w}}(0.51-0.69)$, reducing sugars

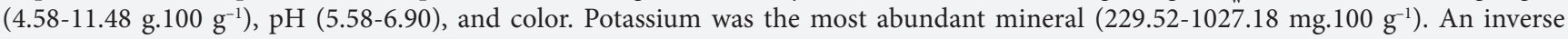
relationship between IS and transmittance at $720 \mathrm{~nm}\left(\mathrm{R}^{2}=0.96\right)$ and a direct relationship between IS and ash $\left(\mathrm{R}^{2}=0.94\right)$ were found. The sulphur dioxide test was negative for all the samples.

Keywords: sweetener; sugar cane; artisanal; minerals; reducing sugars; insoluble solids; panelas; physical and chemical properties.
\end{abstract}

\section{Resumo}

A rapadura é um adoçante natural obtido pela concentração do suco de cana-de-açúcar e elaborado artesanalmente em pequenas fábricas. No estudo realizado, se determinaram as propriedades físicas e químicas de rapaduras granuladas artesanais de duas marcas comerciais e de uma produzida em nível experimental. Analisaram-se três lotes de cada amostra. Os parâmetros medidos foram umidade, $a_{w}$, proteína, cinzas, minerais, açúcares redutores, sacarose, $\mathrm{pH}$, cor (L, a e b), sólidos insolúveis (SI), turbidez e filtrabilidade. Também se realizou uma prova qualitativa para detectar dióxido de enxofre. Os parâmetros de maior variabilidade foram umidade (1.66-4.36 g.100 g $\left.{ }^{-1}\right)$, a $(0.51-0.69)$, açúcares redutores (4.58-11.48 g.100 g $\left.\mathrm{g}^{-1}\right), \mathrm{pH}$ (5.58-6.90) e cor. O potássio foi o mineral mais abundante. Encontrou-se uma relação inversa entre SI e turbidez $\left(R^{2}=0,96\right)$ e uma relação direta entre SI e cinzas $\left(R^{2}=0,94\right)$. A prova de dióxido de enxofre resultou negativa para todas as amostras.

Palavras-chave: adoçante; cana-de-açúcar; artesanal; minerais; açúcares redutores; sólidos insolúveis; rapadura; propriedades físicas e químicas.

\section{Introduction}

Panela is a solid natural product, obtained by concentrating sugar cane juice previously clarified (NTC 1311, 1991), and traditionally commercialized in blocks of different shapes and sizes. This foodstuff can be considered a whole sweetener (KUMAR; TIWARI, 2006), as it preserves most of the compounds present in sugar cane juice, and therefore, it is expected that its nutritional value is higher than that of refined sugar.

It has been shown that panela has medicinal properties, for example, preventing lung lesions induced by smoke, due to its antitoxigenic and anticarcinogenic properties (SAHU; PAUL, 1998; SAHU; SAXENA, 1994) and to the reduction of the clastogenic effect caused by arsenic (SINGH et al., 2008; HAIDER et al., 2007; SINGH; KUMAR; SAHU, 2006). In addition, it has a potential antioxidant activity owing to the presence of polyphenolic compounds in cane juice (HARISH et al., 2009; PAYET; CHEONG; SMADJA, 2006).

Panela is known by many different names: "gur" and "jaggery" in India and Pakistan, "rapadura" in Brazil, "chancaca" in Chile and Peru, "panela" in Colombia, Ecuador, Guatemala and other Central American countries, "panela" or "piloncillo" in Mexico, and "papelón" or "panela" in Venezuela. FAO statistics record it as uncentrifuged sugar.

Panela is produced in 25 countries, Venezuela among them, with a world annual production of 11.05 million tonnes (FAOSTAT, 2003). The manufacture of panela is concentrated in Asia and South America, the major producers being India (6.89 million tonnes) and Colombia (1.50 million panela tonnes).

On a world scale, the agro-industry rural in nature, with a clearly artisanal process controlled by the experience of the operators, which leads to the lack of standardization in both the process and the quality of the product (MUJICA; GUERRA; SOTO, 2008; MOSQUERA; CARRERA; VILLADA, 2007; HERNÁNDEZ; AMAYA; GIRALDO, 2002; PAWAR; DONGARE, 2001). This, together with the little knowledge consumers have about the nutritional and medicinal benefits of

Recebido para publicação em 18/5/2008

Aceito para publicação em 8/7/2009 (003523)

${ }^{1}$ Departamento de Tecnología de Procesos Biológicos y Bioquímicos, Universidad Simón Bolívar, Caracas 1090A, Venezuela, E-mail: mguerra@usb.ve

${ }^{2}$ Departamento de Procesos Agroindustriales, Universidad Centroccidental Lisandro Alvarado, Barquisimeto 3001, Venezuela

${ }^{*}$ A quem a correspondência deve ser enviada 
the panela and the impractical use of its traditional presentations, contributes to its consumption being much lower compared to that of refined sugar.

The development of new presentations is one of the strategies to promote the consumption of panela. The granulated product, a form that has recently entered the Latin American market, is obtained by concentrating sugar cane juice until a thick syrup is achieved, which granulates when beaten (NTE INEN 2 332, 2002). In some cases, an air current (at room temperature) by forced convection is applied, simultaneously to beating, to promote dehydration of the product and thus its granulation.

The use of the granulated product has advantages compared to the block presentation, as it is easier to measure, more stable during storage, and more soluble. Due to its high proportion of sucrose and the advantages already mentioned, it can be used in the same way as sugar (beverages, desserts, and sweet and sour preparations).

The objective of this research was to determine the physical and chemical properties of artisanal granulated panelas and of one produced at experimental level. Three lots were analyzed from each sample, in order to characterize the product and evaluate the variability among samples and among lots. In addition, some variables were correlated in order to find the most suitable ones to evaluate the quality of the product.

\section{Materials and methods}

\subsection{Sample acquisition}

Two commercial brands, A and B, produced in two municipalities of the Tachira State, in the west of the Venezuela, were analyzed. The experimental panela was manufactured at a pilot plant level by the CIEPE (Centro de Investigaciones del Estado para la Producción Experimental Agroindustrial) Foundation. Three lots of each product were analyzed, and in all cases, the sampling took place at the production site.

\subsection{Sample preparation}

Prior to the analysis, the samples were ground in a mill (HQ Analyzer MC-II, Argentina) up to a particle size smaller than $0.6 \mathrm{~mm}$.

\subsection{Physical and chemical characterization}

\section{Moisture, protein, ash, reducing sugars and sucrose}

Official AOAC (1990) methods for sugars and sugary products were used. The nitrogen content was multiplied by 6.25 to calculate the protein concentration in the sample. Results were reported on dry basis (except moisture) in g. $100 \mathrm{~g}^{-1}$ of sample.

\section{Minerals}

Minerals analyzed were potassium, calcium, phosphorus, magnesium, sodium, iron, zinc, manganese, and copper, using inductively coupled plasma-atomic emission spectroscopy (ICP GBC Integra XL, Australia).
Previously, a solution of ashes was prepared following the Venezuelan standard COVENIN 1178-83 (1983). To the residue of the ash determination, $5 \mathrm{~mL}$ of a hydrochloric acid solution (1:1) were added and heated on an electric hot plate until dry; another $5 \mathrm{~mL}$ were added and it was heated for 30 minutes. The resulting solution was filtered to a $100 \mathrm{~mL}$ volumetric flask, the filter paper with the remaining insoluble ash residue was incinerated and $5 \mathrm{~mL}$ of hydrochloric acid (1:1) were added, and it was heated for 5 minutes. This solution was filtered into the same volumetric flask, the crucible was rinsed, and the flask was filled to capacity with distilled water. A reagent blank solution was prepared likewise. The concentration of each mineral was expressed as mg.100 $\mathrm{g}^{-1}$ sample (dry basis).

$a_{w}$

Water activity was determined using a Decagon CX-2 (AquaLab, USA), which uses a psychrometric method based on the "cooled mirror" technique.

$p H$

$\mathrm{pH}$ was determined with a $\mathrm{pH}$ Meter (Coleman 39, USA) in a $10 \% \mathrm{w} / \mathrm{w}$ panela solution, at room temperature, following a modified version of the Prada (2002) method.

\section{Color}

Tristimulus color was determined using a spectrocolorimeter (Hunterlab Miniscan XE 45/0, USA). The readings were performed in terms of $\mathrm{L}$, $\mathrm{a}$ and $\mathrm{b}$. Lightness value, $\mathrm{L}$, indicates how dark/light the sample is (varying from 0-black to 100 -white), a is a measure of greenness/redness (varying from -60 to +60 ), and $b$ is the grade of blueness/yellowness (also varying from -60 to +60 ). For each replica, the mean of three readings was taken.

\section{Insoluble solids}

Insoluble solids were quantified with a modified version of the Prada (2002) method. $2.5 \mathrm{~g}$ of sample were weighed, and $20 \mathrm{~mL}$ of distilled water were added; it was agitated on an electric hot plate for 30 minutes and filtered through a MFS membrane with a pore diameter of $0.45 \mu \mathrm{m}$, made with a mixture of cellulose esters, in a stainless steel filtration unit (Sartourius A G 16828, Germany). Once the sample was suctioned, two rinses of the membrane were performed with $30 \mathrm{~mL}$ of distilled water; this was later dried in an oven (Memmert 25, Germany) at $100{ }^{\circ} \mathrm{C}$ for 3 hours. It was weighed, and the dehydration process continued until a constant weight was achieved. The content of insoluble solids was expressed as g per $100 \mathrm{~g}$ dry basis.

\section{Turbidity (transmittance a $720 \mathrm{~nm}$ )}

The analysis was performed with a modified version of the Prada (2002) method. For this, a solution of the sample at 5\% $\mathrm{w} / \mathrm{v}$ (dry basis) was prepared and divided in two portions; one of them was filtered through a paper equivalent to a Whatman $\mathrm{N}^{\circ} 1$ using siliceous earth as filtering aid and used as a blank. The second portion was used to measure the percentage of 
transmittance at $720 \mathrm{~nm}$ in a spectrophotometer (Milton Roy Spectronic 21D, USA).

\section{Filterability}

Filterability was measured following the method described in the Venezuelan standard COVENIN 3111-94 (1994), in which the rate of filtration of a solution of the sample is compared to the one of a solution of pure sucrose, under the same conditions. $200 \mathrm{~mL}$ of a solution of pure sucrose $\left(28^{\circ}\right.$ Brix $)$ were filtered through paper equivalent to a Whatman $\mathrm{N}^{\circ} 91$ and after three minutes, the filtered volume was measured. This procedure was repeated for the sample and its percentage of filterability calculated with the ratio of filtered volumes.

\section{Sulfur dioxide detection}

The qualitative method specified on the standard COVENIN 1289-78 (1978) was applied. In order to do this, $25 \mathrm{~g}$ of sample were weighed, transferred to an Erlenmeyer flask, and distilled water was added to complete $50 \mathrm{~mL} ; 3$ zinc stones and $4 \mathrm{~mL}$ of hydrochloric acid at $37 \%$ were also added. Next, a paper circle impregnated with a saturated solution of lead acetate was placed on the mouth of the flask, and it was gently heated until boiling for a few seconds. The darkening of the paper shows the presence of sulfur dioxide by the formation of lead sulfide.

\section{Statistical analysis}

All analyses were performed in triplicate. The results were reported as the mean value \pm standard deviation. A variance analysis was applied to determine significant differences $(\alpha=0.05)$. For the comparison of the means, a Duncan multiple range test $(\alpha=0.05)$ was applied.

\section{Results and discussion}

\subsection{Moisture, protein, ash, reducing sugars and sucrose}

In Table 1, the results for moisture, protein, ash, reducing sugars and sucrose are shown. It is observed that the lowest moisture was found in the artisanal panelas, for which all the lots of the same brand were significantly different. The moisture content for these panelas was lower than that of brown sugar ( $\left.3.0 \mathrm{~g} .100 \mathrm{~g}^{-1}\right)$, according to the specifications of the food composition table of the Venezuelan National Institute of Nutrition (INN, 2001). In addition, it agreed with what was reported by Fajardo et al. (1999), for the samples from three regions of Colombia, with a mean moisture content of $2.33 \mathrm{~g} .100 \mathrm{~g}^{-1}$. The experimental panela showed the highest moisture, being even higher than the $3 \mathrm{~g} .100 \mathrm{~g}^{-1}$, established as the maximum limit by the Ecuadorian Technical Standard (NTE INEN 2 332, 2002).

The protein content was higher for the experimental panela, and it had a higher variability among lots. The artisanal panelas brands $\mathrm{A}$ and $\mathrm{B}$ presented similar values between them, of 0.40 and $0.60 \mathrm{~g} .100 \mathrm{~g}^{-1}$, respectively. The results obtained are in agreement with those reported by Prada (1997), from 0.5 to $0.8 \mathrm{~g} .100 \mathrm{~g}^{-1}$, by García (2003), between 0.65 and $0.87 \mathrm{~g} .100 \mathrm{~g}^{-1}$, and by Rodríguez and Segura (2004), from 0.69 to $0.75 \mathrm{~g} .100 \mathrm{~g}^{-1}$. The Ecuadorian technical standard (NTE INEN 2 332, 2002) establishes that the minimum content of protein in granulated panela must be $0.5 \mathrm{~g} .100 \mathrm{~g}^{-1}$, while for the Colombian technical standard (NTC 1311, 1991) the minimum is $0.2 \mathrm{~g} .100 \mathrm{~g}^{-1}$ and therefore, both the experimental and commercial panelas fulfilled this requirement.

The ash content varied between 1.15 and $2.63 \mathrm{~g} .100 \mathrm{~g}^{-1}$, being significantly higher in the samples of brand A; both the experimental panela and the commercial brand B had similar values. Among the lots of experimental panela, no significant differences were detected, and in the artisanal panelas, there was little variability. The results coincide with those found by García (2003) in samples of different Colombian regions, with a mean ash content between 1.15 and $2.05 \mathrm{~g} .100 \mathrm{~g}^{-1}$, and also with the values reported by Rodríguez and Segura (2004) in Peruvian panelas, from 1.22 to $1.38 \mathrm{~g} .100 \mathrm{~g}^{-1}$. The Colombian technical standard NTC 1311 (1991) establishes a range for the ash content between 0.80 to $1.90 \mathrm{~g} .100 \mathrm{~g}^{-1}$. The experimental panela and the artisanal brand $\mathrm{B}$ complied with this requirement, while the $\mathrm{A}$ brand value was found to be above the upper limit.

Table 1. Content of moisture, protein, ash, reducing sugars (RS) and saccharose (g.100 g $\left.\mathrm{gB}^{-1}\right)$.

\begin{tabular}{|c|c|c|c|c|c|c|}
\hline Sample & Lot & Moisture & Protein & Ash & RS & Saccharose \\
\hline \multirow[t]{4}{*}{ Experimental } & 1 & $4.34 \pm 0.07^{\mathrm{fg}}$ & $0.75 \pm 0.01^{c}$ & $1.35 \pm 0.01^{\mathrm{b}}$ & $5.52 \pm 0.10^{c}$ & $86.2 \pm 0.3^{\mathrm{d}}$ \\
\hline & 2 & $4.36 \pm 0.08^{g}$ & $0.57 \pm 0.02^{b}$ & $1.40 \pm 0.01^{\mathrm{b}}$ & $5.58 \pm 0.15^{c}$ & $87.4 \pm 0.6^{\mathrm{e}}$ \\
\hline & 3 & $4.28 \pm 0.05^{\mathrm{f}}$ & $1.30 \pm 0.07^{\mathrm{d}}$ & $1.42 \pm 0.01^{\mathrm{b}}$ & $4.58 \pm 0.06^{\mathrm{a}}$ & $84.5 \pm 0.7^{c}$ \\
\hline & mean & 4,33 & 0,87 & 1,39 & 5,23 & 86,03 \\
\hline \multirow[t]{4}{*}{ Artisanal brand A } & 1 & $2.36 \pm 0.03^{\mathrm{b}}$ & $0.43 \pm 0.02^{\mathrm{a}}$ & $2.42 \pm 0.08^{c}$ & $11.48 \pm 0.17^{\mathrm{h}}$ & $80.3 \pm 1.2^{\mathrm{a}}$ \\
\hline & 2 & $1.66 \pm 0.02^{\mathrm{a}}$ & $0.60 \pm 0.03^{b}$ & $2.63 \pm 0.04^{\mathrm{d}}$ & $10.85 \pm 0.12^{\mathrm{g}}$ & $79.9 \pm 0.6^{\mathrm{a}}$ \\
\hline & 3 & $2.48 \pm 0.02^{c}$ & $0.57 \pm 0.02^{b}$ & $2.62 \pm 0.09^{d}$ & $9.63 \pm 0.15^{\mathrm{f}}$ & $82.9 \pm 0.6^{\mathrm{b}}$ \\
\hline & mean & 2,17 & 0,53 & 2,56 & 10,65 & 81,03 \\
\hline \multirow[t]{4}{*}{ Artisanal brand B } & 1 & $2.57 \pm 0.06^{\mathrm{d}}$ & $0.57 \pm 0.02^{b}$ & $1.33 \pm 0.02^{\mathrm{b}}$ & $7.40 \pm 0.09^{\mathrm{e}}$ & $85.1 \pm 0.7^{c}$ \\
\hline & 2 & $2.29 \pm 0.02^{\mathrm{b}}$ & $0.57 \pm 0.02^{\mathrm{b}}$ & $1.34 \pm 0.01^{\mathrm{b}}$ & $4.98 \pm 0.07^{\mathrm{b}}$ & $88.1 \pm 0.5^{\mathrm{e}}$ \\
\hline & 3 & $3.14 \pm 0.02^{\mathrm{e}}$ & $0.40 \pm 0.01^{\mathrm{a}}$ & $1.15 \pm 0.01^{\mathrm{a}}$ & $5.76 \pm 0.13^{\mathrm{d}}$ & $86.3 \pm 1.1^{\mathrm{d}}$ \\
\hline & mean & 2,67 & 0,51 & 1,27 & 6,05 & 86,50 \\
\hline
\end{tabular}

Equal letters in the same column indicate no significant differences $(\mathrm{p}>0.05)$. ${ }^{\mathrm{a}}$ Dry basis, except for moisture. 
Reducing sugars turned out to be significantly higher in the artisanal brand A sample, compared to brand B and to the experimental one. The Ecuadorian technical standard (NTE INEN 2 332, 2002) dictates that reducing sugars must be between 5.5 and $10.0 \mathrm{~g} .100 \mathrm{~g}^{-1}$, while the upper limit for the Colombian technical standard NTC 1311 (1991) is $12 \mathrm{~g} .100 \mathrm{~g}^{-1}$. Significant differences were found in all the lots of each artisanal sample, perhaps due to uncontrolled process conditions, while the experimental panela showed less variability. García (2003) found that the reducing sugars in panelas from different regions varied between 5.7 and $8.8 \mathrm{~g} .100 \mathrm{~g}^{-1}$. Rodríguez and Segura (2004) obtained granulated panela with 3.70 g. $100 \mathrm{~g} \mathrm{~g}^{-1}$ of reducing sugars. A high content of reducing sugars is undesirable because they increase the hygroscopicity of the panela, affecting its texture and stability during storage (TIWARI; CHATTERJEE, 1998; PATIL; ADSULE, 1998; VERMA; MAHARAJ, 1990).

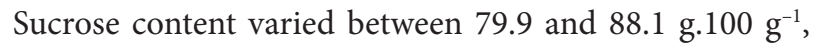
being significantly lower in the brand A artisanal panela, which was expected because it also had the highest content of reducing sugars. The Ecuadorian technical standard (NTE INEN 2 332, 2002) establishes that sucrose content must be between 75 and $83 \mathrm{~g} .100 \mathrm{~g} \mathrm{~g}^{-1}$, while for the Colombian one, this range is from 73 to $83 \mathrm{~g} .100 \mathrm{~g}^{-1}$. The sucrose content in the experimental and in the brand $\mathrm{B}$ artisanal panelas was higher than the maximum limits established by these standards. However, this limit seems low because sucrose is the main component of the panela, followed by the amount of reducing sugars, which cannot be higher than 10.0 or $12 \mathrm{~g} .100 \mathrm{~g}^{-1}$, according to the Ecuadorian and Colombian standards, respectively. For Prada (1997), the sucrose content of the granulated panela varies between 84 and 86 g. $100 \mathrm{~g}^{-1}$; García (2003) recorded values between 80.4 and $85.8 \mathrm{~g} .100 \mathrm{~g} \mathrm{~g}^{-1}$, and Rodríguez and Segura (2004) reported values in the range of 89.18 to $89.78 \mathrm{~g} .100 \mathrm{~g}^{-1}$.

\subsection{Minerals}

In Table 2, the mineral contents of the panelas evaluated are shown. $\mathrm{K}$ had the highest concentration, followed by $\mathrm{Ca}$ in most of the lots. This was to be expected since $\mathrm{K}$ is the mineral with the major content in sugar cane juice (SALGADO et al., 2003; CHEN, 1991). The highest content of $\mathrm{K}, \mathrm{Ca}, \mathrm{P}, \mathrm{Na}, \mathrm{Fe}$, and $\mathrm{Zn}$ was found in the brand A artisanal panela. The results agree with that determined for the ash content, since the panela that showed the highest ash content, also presented the highest amount of $\mathrm{K}, \mathrm{Ca}$, and $\mathrm{P}$. There was little variability among lots of the same sample; however, there was a wide variability among the samples that could have been due to agro-ecological (cane variety, climate, soil, crop handling) and processing (level of juice extraction, clarifying method, lime purity, impurity removal efficiency) factors.

The percentages of the recommended daily allowance (RDA) of the main minerals which are provided, as reviewed by the Venezuelan National Institution of Nutrition (INN, 2000), are shown in Table 3. Based on a consumption of $50 \mathrm{~g}$ of granulated panela, and assuming that the minerals are bioavailable, approximately $5 \%$ or more of the daily requirements of $\mathrm{Cu}, \mathrm{Fe}$, $\mathrm{Mg}$, and $\mathrm{Ca}$ are met.

\section{$3.3 a_{w}$}

The results for $\mathrm{a}_{\mathrm{w}} \mathrm{pH}$, and color are shown in Table 4 . In general, $\mathrm{a}_{\mathrm{w}}$ values between 0.48 and 0.70 at a mean room temperature of $27.8 \pm 0.8{ }^{\circ} \mathrm{C}$ were found, finding significant differences among lots for all the samples. The highest value was found for the experimental panela, and the lowest one was found for the brand A artisanal panela. Comparing the $\mathrm{a}_{\mathrm{w}}$ values to the moisture values, it was found that the greater the moisture, the higher the $\mathrm{a}_{\mathrm{w}}$, which agrees with what was reported by Verma and Maharaj (1990) for block panela. The high $\mathrm{a}_{\mathrm{w}}$ values promote microbial deterioration and biochemical degradation reactions, and therefore, the brand $\mathrm{A}$ artisanal panela is the most stable one. Brand $B$ artisanal panela showed $a_{w}$ values lying in the range of growth (0.60-0.65) of osmophilic yeasts (Saccharomyces rouxii) and of some moulds (Aspergillus equinulatus and Monascus bisporus), according to Beuchat (1981). On the other hand, in the experimental panela, with the highest $\mathrm{a}_{w}$, xerophilic moulds (Aspergillus chevalieri and Aspergillus candidus, among others) can grow, and the yeast Saccharomyces bisporus, in addition to the microorganisms previously mentioned.

\section{$3.4 \mathrm{pH}$}

$\mathrm{pH}$ measured in a $10 \%$ panela solution, such as $\mathrm{a}_{\mathrm{w}}$, proved to be significantly different in all the lots evaluated, varying from 5.58 to 6.90 . This range was broader than that reported by García (2003), between 5.74 and 6.47 .

The Ecuadorian technical standard NTE INEN 2332 (2002) establishes a minimum $\mathrm{pH}$ of 5.90, the artisanal samples being over this value, and the experimental one a little under it. Lower $\mathrm{pH}$ values can be related to a deficient quantity of lime in the clarifying of the juice, which hinders the removal of impurities and in addition, promotes sucrose inversion. The Colombian standard does not regulate this variable.

\subsection{Color}

All the lots of artisanal panelas showed significant differences with respect to luminosity (L), which indicates lack of control during the process. Regarding the experimental panela, only lot 3 proved to be significantly darker. According to Mungare et al. (2000), color is the predominant factor in the quality of the panela, and in India, it is used as the criterion for the classification of this product. Several authors state that the light colored panelas, light golden yellow or light brown, are preferred by consumers (RODRÍGUEZ; SEGURA, 2004; TIWARI; CHATTERJEE, 1998; PATIL; ADSULE, 1998). The color of the panela depends on the amount of dark compounds generated during extraction and heating of the cane juice, which could be derived from: i) oxidation of phenolic compounds; ii) caramelization of sucrose, glucose and fructose; iii) Maillard reaction; and iv) alkaline decomposition of sucrose (CHEN, 1991; DAMODARAN, 2000).

The "a" parameter of the Hunter scale was positive for all the samples, and thus all red tones were characteristic of the panelas. All the lots of the experimental panela and of brand B artisanal panela showed "a" values significantly different, and for the brand A commercial artisanal panela, only lot 2 had 


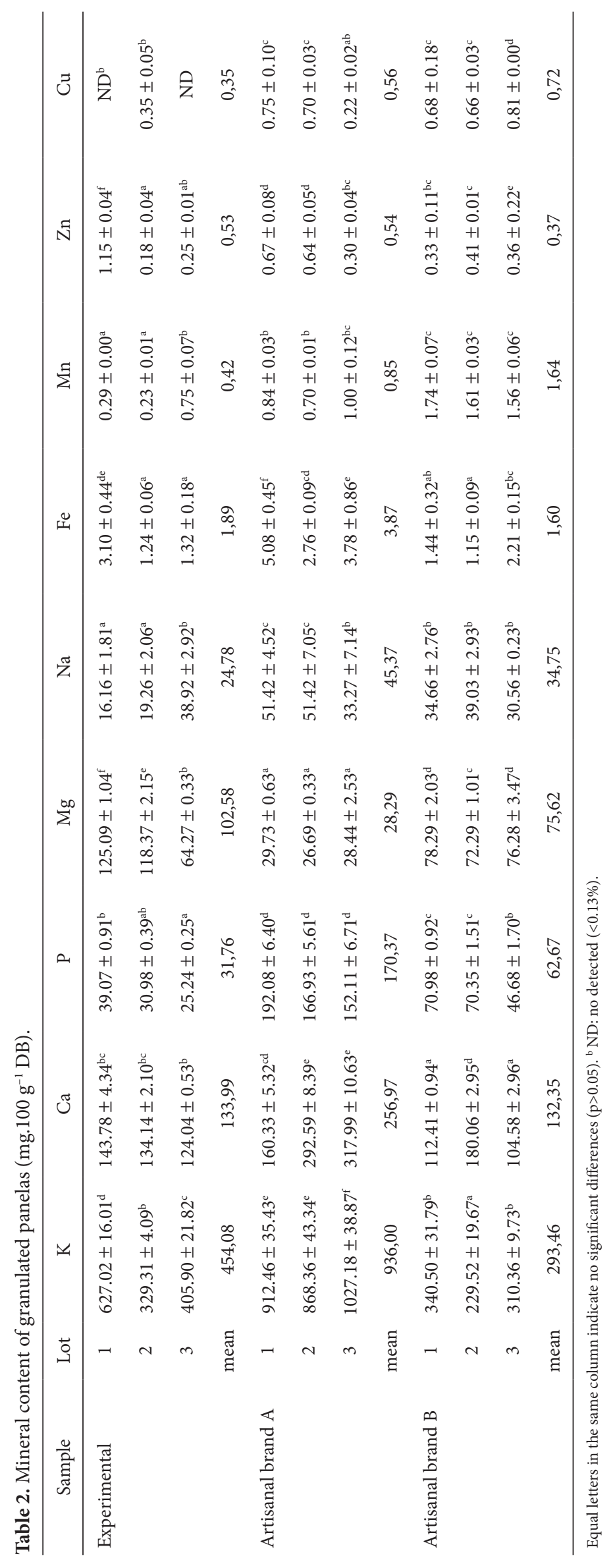


a significantly higher value, and the lowest one was for the experimental sample.

As with "a", the "b" parameter was positive for all the samples, and thus the color was characterized by the combination of red and yellow tones.

\subsection{Insoluble solids (IS), turbidity (transmittance at $720 \mathrm{~nm}$ ), and filterability}

The insoluble solid content in the panelas analyzed varied significantly from one lot to another (Table 5); for both the experimental panela and brand A commercial panela, only a couple of lots did not present significant differences (2-3 and 1-2, respectively). The highest insoluble solid content was found in the brand A commercial panela, followed by the experimental panela, and in last place was the brand B commercial panela.

Insoluble solids represent an important quality parameter, especially when the panela is going to be used in the preparation of beverages, and it is used by the Ecuadorian and Colombian technical standards as criterion for classification. These standards employ categories: extra, first and second, which require a maximum of $0.1,0.5$ and $1.0 \%$ IS, respectively. Therefore, taking into account this criterion alone, the brand A commercial panela can be classified as "second", and the experimental and brand B commercial panelas as a "first".

Table 3. Mineral supply (Cu, Fe, $\mathrm{Zn}, \mathrm{Mg}, \mathrm{P}$ and $\mathrm{Ca}$ ) in $50 \mathrm{~g}$ of granulated panela.

\begin{tabular}{lrrrrrr}
\hline \multirow{2}{*}{ Panela } & \multicolumn{6}{c}{ \% of the recommended daily intake } \\
\cline { 2 - 7 } & \multicolumn{1}{c}{$\mathrm{Cu}$} & \multicolumn{1}{c}{$\mathrm{Fe}$} & $\mathrm{Zn}$ & \multicolumn{1}{c}{$\mathrm{Mg}$} & \multicolumn{1}{c}{$\mathrm{P}$} & \multicolumn{1}{c}{$\mathrm{Ca}$} \\
\hline Experimental & 5.00 & 7.88 & 2.04 & 17.39 & 2.37 & 6.70 \\
Artisanal brand A & 14.00 & 16.12 & 2.08 & 4.79 & 12.71 & 12.85 \\
Artisanal brand B & 18.00 & 6.67 & 1.42 & 12.82 & 4.68 & 6.62 \\
\hline
\end{tabular}

The results agree with those reported by Prada (2002) for the characterization of the cleaning systems of 25 Colombian units of panela production. (0.4 to $1.6 \mathrm{~g} .100 \mathrm{~g}^{-1}$ insoluble solids).

In addition, it was found that the higher the ash content in the panela, the higher its percentage of insoluble solids, with a correlation coefficient $\left(\mathrm{R}^{2}\right)$ of 0.94 . Regarding this, Chen (1991) affirms that the inorganic compounds of sugar cane can be present as ions, molecules, salts, components of complex organic molecules, or as insoluble compounds.

The panela with the lowest turbidity (highest transmittance a $720 \mathrm{~nm}$ ) was commercial brand B, and the one with the highest turbidity was commercial brand A.

For both the artisanal panelas and the experimental panela, the samples with the highest content of insoluble solids showed the lowest transmittance at $720 \mathrm{~nm}$, that is, they were the most turbid. When these two variables were correlated, a correlation coefficient, $\mathrm{R}^{2}, 0.96$ was obtained. This means that at research level, transmittance at $720 \mathrm{~nm}$ could be used as a measure of insoluble solids, since it is a faster analysis.

Regarding filterability, in each type of panela, one of the lots was significantly different from the rest. Filterability was correlated inversely to turbidity and to insoluble solid content, and the coefficient $\mathrm{R}^{2}$ was 0.73 and 0.76 , respectively. From this, it can be inferred that turbidity, measured by transmittance at $720 \mathrm{~nm}$, is a better indicator of the insoluble solid content compared to filterability.

\subsection{Sulfur dioxide detection}

The test for the detection of sulfur dioxide was negative for all lots of both the experimental panela and the artisanal ones. The Ecuadorian and Colombian technical standards state that the panela must be free from sulfur compounds and other bleaching substances. In India, organizations such as the "Bureau of Indian Standards" and the "Prevention of Food Adulteration" allow a maximum $\mathrm{SO}_{2}$ content of 50 and $70 \mathrm{ppm}$, respectively.

Table 4. $\mathrm{pH}, \mathrm{a}_{\mathrm{w}}$ and colour of granulated panelas.

\begin{tabular}{|c|c|c|c|c|c|c|}
\hline \multirow[t]{2}{*}{ Sample } & \multirow[t]{2}{*}{ Lot } & \multirow[t]{2}{*}{$\mathrm{pH}(\mathrm{sol} .10 \% \mathrm{p} / \mathrm{p})$} & \multirow{2}{*}{$a_{w}$} & \multicolumn{3}{|c|}{ Tristimulus colour (Hunter escale) } \\
\hline & & & & $\mathrm{L}$ & $\mathrm{a}$ & $\mathrm{b}$ \\
\hline \multirow[t]{4}{*}{ Experimental } & 1 & $6.15 \pm 0.01^{\mathrm{d}}$ & $0.705 \pm 0.002^{\mathrm{i}}$ & $72.27 \pm 1.67^{f}$ & $2.57 \pm 0.14^{\mathrm{a}}$ & $13.39 \pm 0.39^{\mathrm{a}}$ \\
\hline & 2 & $5.58 \pm 0.03^{\mathrm{a}}$ & $0.694 \pm 0.003^{\mathrm{h}}$ & $73.33 \pm 1.27^{\mathrm{f}}$ & $3.24 \pm 0.08^{\mathrm{b}}$ & $13.44 \pm 0.16^{\mathrm{a}}$ \\
\hline & 3 & $5.75 \pm 0.00^{\mathrm{b}}$ & $0.685 \pm 0.005^{g}$ & $62.60 \pm 1.52^{\mathrm{e}}$ & $5.84 \pm 0.09^{c}$ & $16.14 \pm 0.29^{d}$ \\
\hline & mean & 5,83 & 0,690 & 69,40 & 3,88 & 14,32 \\
\hline \multirow[t]{2}{*}{ Artisanal brand A } & 1 & $6.07 \pm 0.03^{c}$ & $0.517 \pm 0.001^{\mathrm{b}}$ & $55.18 \pm 0.44^{\mathrm{cd}}$ & $8.94 \pm 0.18^{\mathrm{f}}$ & $17.37 \pm 0.43^{\mathrm{e}}$ \\
\hline & mean & 6,50 & 0,51 & 50,82 & 9,51 & 15,68 \\
\hline \multirow[t]{4}{*}{ Artisanal brand B } & 1 & $6.50 \pm 0.00^{f}$ & $0.570 \pm 0.002^{\mathrm{d}}$ & $50.85 \pm 1.36^{\mathrm{b}}$ & $9.26 \pm 0.42^{\mathrm{f}}$ & $15.09 \pm 0.70^{c}$ \\
\hline & 2 & $6.90 \pm 0.00^{\mathrm{i}}$ & $0.619 \pm 0.001^{\mathrm{e}}$ & $53.59 \pm 0.74^{\mathrm{c}}$ & $8.08 \pm 0.11^{\mathrm{e}}$ & $15.71 \pm 0.23^{\text {cd }}$ \\
\hline & 3 & $6.25 \pm 0.00^{\mathrm{e}}$ & $0.653 \pm 0.003^{\mathrm{f}}$ & $56.77 \pm 3.08^{\mathrm{d}}$ & $7.16 \pm 0.17^{\mathrm{d}}$ & $15.96 \pm 0.13^{\mathrm{d}}$ \\
\hline & mean & 6,55 & 0,61 & 53,74 & 8,17 & 15,59 \\
\hline
\end{tabular}

Equal letters in the same column indicate no significant differences $(\mathrm{p}>0.05)$ 
Table 5. Insoluble solids (IS), turbidity, and filterability of granulated panelas.

\begin{tabular}{lcccc}
\hline \multicolumn{1}{c}{ Sample } & Lot & $\begin{array}{c}\text { IS } \\
\left(\mathrm{g} .100 \mathrm{~g}^{-1} \mathrm{DB}\right)\end{array}$ & $\begin{array}{c}\text { Turbidity }(\% \\
\text { Transmittance })\end{array}$ & $\begin{array}{c}\text { Filterability } \\
(\%)\end{array}$ \\
\hline Experimental & 1 & $0.39 \pm 0.01^{\mathrm{c}}$ & $78.2 \pm 0.00^{\mathrm{c}}$ & $17 \pm 0.58^{\mathrm{d}}$ \\
& 2 & $0.43 \pm 0.01^{\mathrm{d}}$ & $87.0 \pm 0.14^{\mathrm{g}}$ & $23 \pm 0.58^{\mathrm{e}}$ \\
& 3 & $0.43 \pm 0.01^{\mathrm{d}}$ & $79.9 \pm 0.28^{\mathrm{d}}$ & $22 \pm 1.15^{\mathrm{e}}$ \\
& mean & 0,42 & 81,70 & 20,67 \\
Artisanal & 1 & $0.90 \pm 0.02^{\mathrm{e}}$ & $60.4 \pm 0.44^{\mathrm{b}}$ & $11 \pm 0.58^{\mathrm{b}}$ \\
brand A & 2 & $0.89 \pm 0.00^{\mathrm{e}}$ & $59.4 \pm 0.80^{\mathrm{b}}$ & $11 \pm 0.58^{\mathrm{b}}$ \\
& 3 & $1.16 \pm 0.01^{\mathrm{f}}$ & $47.2 \pm 0.52^{\mathrm{a}}$ & $8 \pm 0.58^{\mathrm{a}}$ \\
& mean & 0,98 & 55,67 & 10,00 \\
Artisanal & 1 & $0.38 \pm 0.01^{\mathrm{c}}$ & $82.4 \pm 0.30^{\mathrm{e}}$ & $13 \pm 0.00^{\mathrm{c}}$ \\
brand B & 2 & $0.33 \pm 0.01^{\mathrm{b}}$ & $84.8 \pm 0.49^{\mathrm{f}}$ & $14 \pm 0.58^{\mathrm{c}}$ \\
& 3 & $0.26 \pm 0.00^{\mathrm{a}}$ & $86.9 \pm 0.13^{\mathrm{g}}$ & $16 \pm 0.58^{\mathrm{d}}$ \\
& mean & 0,32 & 84,70 & 14,33 \\
\hline
\end{tabular}

Equal letters in the same column indicate no significant differences $(p>0.05)$.

The use of sodium hydrosulfite to decrease the color intensity of the panela is a common practice in that country, and levels of 450 to 500 ppm have been found (PATIL; ADSULE, 1998).

\section{Conclusions}

In general, the granulated panelas evaluated are almost entirely made up of sugars (mainly sucrose), and of a small quantity of other components (water, ash, proteins and insoluble solids). In addition, the presence of an important group of minerals ( $\mathrm{K}, \mathrm{Ca}, \mathrm{P}, \mathrm{Mg}, \mathrm{Na}, \mathrm{Fe}, \mathrm{Mn}, \mathrm{Zn}$ and $\mathrm{Cu}$ ) was proven, which add to nutritional benefits of panela. The results obtained can be used in the national table of food composition and in the FAO databases for Latin American foodstuffs.

On the other hand, given the high variability found, mainly in the artisanal granulated panelas, the generation and adaptation of basic technology leading to the standardization of the process is recommended. The formulation of a Venezuelan quality standard for the panela in its different presentations is also important.

\section{Acknowledgements}

The authors wish to extend thanks to Deanship of Postgraduate Studies of the Simon Bolivar University and to FONACIT for financing this research. Also, to the CIEPE Foundation and to the artisanal producers for supplying the samples of granulated panela.

\section{References}

ASSOCIATION OF OFFICIAL ANALYTICAL CHEMIST - AOAC. Official methods of analysis. 15 ed. Washington, 1990.

BEUCHAT, L. R. Microbial stability as affected by water activity. Cereal Foods World, v. 26, n. 7, p. 345-349, 1981.

CHEN, J. Manual del azúcar de caña. México: Limusa, 1991.
DAMODARAN, S. Aminoácidos, péptidos y proteínas. In: FENEMMA, O. (ed.). Química de alimentos. 2 ed. España: Acribia, 2000. p. 490.

FAJARDO, B. et al. Determinación de algunas propiedades físicas y mecánicas de la panela granulada. Revista Ingeniería e Investigación, v. 43, p. 34-39, 1999.

FAOSTAT. Producción de caña de azúcar y de azúcar no centrifugado. Italy, 2003. Disponível em: <http://faostat.fao.org/>. Acesso em: 8 jun. 2005. (Database FAO)

FONDONORMA. COVENIN 1289-78. Frutas, vegetales y productos derivados: determinación de dióxido de azufre (SO2). Venezuela, 1978.

FONDONORMA. COVENIN 1178-83. Alimentos: determinación de fósforo. Venezuela, 1983.

FONDONORMA. COVENIN 3111-94. Azúcar: determinación de la filtrabilidad. Venezuela, 1994.

GARCÍA, H. R. Mejoramiento de los sistemas de moldeo y de presentación de la panela a nivel de pequeño y mediano productor. Colombia: CIMPA, 2003.

HAIDER, F. et al. Genotoxicity induced by long term exposure to arsenic in mice and its modulation by supplementary diet of Jaggery. Toxicology Letters, v. 172, n. 1, p. S117-S118, 2007.

HARISH, M. A. et al. Cytoprotective and antioxidant activity studies of jaggery sugar. Food Chemistry, v. 115, n. 1, p. 113-118, 2009.

HERNÁNDEZ, E.; AMAYA, F.; GIRALDO, H. Alternativas tecnológicas para la producción de caña panelera. $2 \mathrm{ed}$. Venezuela: Dirección de Desarrollo Económico, 2002.

INSTITUTO COLOMBIANO DE NORMAS TÉCNICAS Y CERTIFICACIÓN - ICONTEC. NTC 1311. Productos agrícolas: panela. Colombia, 1991.

INSTITUTO ECUATORIANO DE NORMALIZACIÓN - INEN. NTE INEN 2 332. Panela granulada: requisitos. Ecuador, 2002.

INSTITUTO NACIONAL DE NUTRICIÓN - INN. Valores de referencia de energía y nutrientes para la población venezolana. Venezuela, 2000. (Serie de cuadernos azules, 53)

INSTITUTO NACIONAL DE NUTRICIÓN - INN. Tabla de composición de alimentos. Venezuela, 2001. (Serie de cuadernos azules, 54).

KUMAR, A.; TIWARI, G. N. Effect of shape and size on convective mass transfer coefficient during greenhouse drying (GHD) of jaggery. Journal of Food Engineering, v. 73, n. 2, p. 121-134, 2006.

MOSQUERA, S. A.; CARRERA, J. E.; VILLADA, H. S. Variables que afectan la calidad de la panela procesada en el departamento del Cauca. Biotecnología en el Sector Agropecuario y Agroindustrial, v. 5, n. 1, p. 17-27, 2007.

MUJICA, M. V.; GUERRA, M.; SOTO, N. Efecto de la variedad, lavado de la caña y temperatura de punteo sobre la calidad de la panela granulada. Interciencia, v. 33, n. 8, p. 598-603, 2008.

MUNGARE, T. S. et al. Clarification technique for producing quality jaggery. Cooperative Sugar, v. 32, n. 4, p. 283-285, 2000.

PATIL, J. P.; ADSULE, P. G. Studies on various quality parameters for grading of jaggery. Indian Food Industry, v. 17, n. 4, p. 215-217, 1998.

PAYET, B.; CHEONG, S.; SMADJA, J. Evaluation and identification of molecules responsible for the antioxidant activity of materials used in granulated sugar process. In: WORLD CONGRESS OF FOOD SCIENCE AND TECHNOLOGY, 13, 2006, Francia. Proceedings... Francia: IUFoST, 2006. 
PAWAR, S. T.; DONGARE, M. B. Scientific Studies on Jaggery manufacturing process. Cooperative Sugar, v. 32, n. 5, p. 369-374, 2001.

PRADA, L. E. Metodología HACCP: una propuesta para el aseguramiento de la calidad en la panela. In: CENTRO DE INVESTIGACIÓN Y DIVULGACIÓN PARA EL MEJORAMIENTO DE LA INDUSTRIA PANELERA EN COLOMBIA - CIMPA. Memorias del II Curso internacional de caña panelera y su agroindustria. Colombia, 1997. p. 325-335.

PRADA, L. E. Mejoramiento de la calidad de la panela a través del sistema de limpieza de jugos para pequeños y medianos productores. In: CENTRO DE INVESTIGACIÓN Y DIVULGACIÓN PARA EL MEJORAMIENTO DE LA INDUSTRIA PANELERA EN COLOMBIA - CIMPA. Memorias del II Curso internacional de caña panelera y su agroindustria. Colombia, 2002. p. 21-23.

RODRÍGUEZ, A. R.; SEGURA, M. E. Panela granulada ecológica. Antenor Orrego, v. 15, n. 22, p. 47-55, 2004.

SAHU, A. P.; PAUL, B. The role of dietary whole sugar-jaggery in prevention of respiratory toxicity of air toxics and in lung cancer. Toxicology Letters, v. 95, n. 1, p. 154, 1998.
SAHU, A. P.; SAXENA, A. K. Enhanced translocation of particles from lungs by jaggery. Environmental Health Perspectives, v. 102, n. 5, p. 211-214, 1994.

SALGADO, S. et al. Manejo de la fertilización en el rendimiento, calidad del jugo y actividad de invertasas en caña de azúcar. Interciencia, v. 28 , n. 10 , p. 576-580, 2003.

SINGH, N.; KUMAR, D.; SAHU, A. P. Arsenic induced clastogenicity: modulation by functional-food jaggery. Toxicology Letters, v. 164, n. 1, p. S188-S189, 2006.

SINGH, N. et al. Genotoxic effects of arsenic: prevention by functional food-jaggery. Cancer Letters, v. 268, n. 2, p. 325-330, 2008.

TIWARI, R. J.; CHATTERJEE, A. Evaluation of early and mid-late sugarcane (Saccharum officimarum) varieties for yield of millable cane and quality of jaggery. Indian Journal of Agricultural Science, v. 68 , n. 5 , p. 255-257, 1998.

VERMA, V. K.; MAHARAJ, N. Moisture absorption isotherms of jaggery. Journal of Stored Product Research, v. 26, n. 2, p. 61-66, 1990. 